\title{
Stabilization/Solidification of Strontium Using Magnesium Silicate Hydrate Cement
}

\author{
Tingting Zhang $\left.{ }^{1}{ }^{(}\right)$, Jing Zou ${ }^{1}$, Yimiao Li ${ }^{1}$, Yuan Jia ${ }^{2, *}$ and Christopher R. Cheeseman ${ }^{3}$ \\ 1 Faculty of Infrastructure Engineering, Dalian University of Technology, Dalian 116024, China; \\ tingtingzhang@dlut.edu.cn (T.Z.); zou_jing8@mail.dlut.edu.cn (J.Z.); lym_z@mail.dlut.edu.cn (Y.L.) \\ 2 Hebei Provincial Key Laboratory of Inorganic Nonmetallic Materials and Hebei Provincial Industrial Solid \\ Waste Comprehensive Utilization Technology Innovation Center, College of Materials Science and \\ Engineering, North China University of Science and Technology, Tangshan 063210, China \\ 3 Department of Civil and Environmental Engineering, Imperial College London, London SW7 2AZ, UK; \\ c.cheeseman@ic.ac.uk \\ * Correspondence: jia132012@ncst.edu.cn; Tel.: +86-0315-8805020
}

Received: 17 November 2019; Accepted: 30 December 2019; Published: 1 February 2020

\begin{abstract}
Magnesium silicate hydrate (M-S-H) cement, formed by reacting $\mathrm{MgO}, \mathrm{SiO}_{2}$, and $\mathrm{H}_{2} \mathrm{O}$, was used to encapsulate strontium ( $\mathrm{Sr}$ ) radionuclide. Samples were prepared using light-burned magnesium oxide and silica fume, with sodium hexametaphosphate added to the mix water as a dispersant. The performance of the materials formed was evaluated by leach testing and the microstructure of the samples was also characterized. The stabilizing/solidifying effect on $\mathrm{Sr}$ radionuclide in the $\mathrm{MgO}-\mathrm{SiO}_{2}-\mathrm{H}_{2} \mathrm{O}$ system with low alkalinity is demonstrated in the study. The leaching rate in a standard 42-day test was $2.53 \times 10^{-4} \mathrm{~cm} / \mathrm{d}$, and the cumulative 42 -day leaching fraction was $0.06 \mathrm{~cm}$. This meets the relevant national standard performance for leaching requirements. $\mathrm{Sr}^{2+}$ was effectively incorporated into the M-S-H hydration products and new phase formation resulted in low Sr leaching being observed.
\end{abstract}

Keywords: magnesium silicate hydrate; radioactive waste; stabilization/solidification; strontium; leaching

\section{Introduction}

The volume of low level radioactive waste (LLW) and intermediate level radioactive waste (ILW) accounts for $\sim 95 \%$ of the total volume of nuclear waste. Strontium and cesium are important contaminants in LLW and ILW, because these radionuclides are most often present in the cooling water of nuclear reactors. These nuclides have long half-lives $\left({ }^{90} \mathrm{Sr}\right.$ has a half-life of 28.8 years and ${ }^{137} \mathrm{Cs}$ has a half-life of 30.5 years), can readily migrate, and are known to cause carcinogenesis in contaminated living organisms [1-6]. Therefore, the management of low- and intermediate-level radioactive wastes containing $\mathrm{Cs}$ and $\mathrm{Sr}$ remains a major challenge to the nuclear energy industry.

Stabilization/solidification (S/S) includes a broad range of waste treatment technologies, which use asphalt or cementitious materials to convert wastes into a solid form that is more suitable for transportation and long-term storage [7]. Effective solidification transforms a radioactive waste liquid into a solidified material, reducing the potential for radionuclides to migrate into the biosphere and reducing the volume of material requiring storage/disposal. For low- and intermediate-level wastes, solidification in cementitious materials is the preferred option. This uses the hydration and hardening characteristics of Portland cement to achieve physical encapsulation, adsorption, and chemical bonding of the radionuclides. The processing is relatively simple and low cost [8]. However, there are issues with conventional cement stabilization/solidification. These include expansion of the solidified body and the potential for heavy metal salts to retard cement hydration reactions. Therefore, research on 
new types of solidification systems, such as alkali-activated cementitious materials, alkali-slag-clay mineral composite cementitious materials, phosphate cement, and phosphate cement-clay mineral composite systems, is ongoing [9-15].

Alkaline slag cement systems based on metakaolin have been used for the solidification of simulated radioactive wastes and produced low $\mathrm{Cs}^{+}$and $\mathrm{Sr}^{2+}$ leaching rates [11]. However, the $\mathrm{pH}$ of these systems is higher than 12 , which is not conducive to long-term solidification because of the formation of mobile metal complexes. Phosphate cements are also being investigated for solidifying nuclear wastes. These are rapid-setting and hardening and the solidified wastes formed are reported to be resistant to leaching and damage from freeze-thaw cycling [16-18]. However, the setting of phosphate cements is difficult to control and a highly exothermic reaction limits the ability to solidify some types of nuclear waste [19].

Cements that hydrate to form magnesium silicate hydrate (M-S-H gel) are formed from reactions between $\mathrm{MgO}, \mathrm{SiO}_{2}$, and $\mathrm{H}_{2} \mathrm{O}$, and these can have a low porosity, large specific surface area, high strength, low heat of hydration, and low $\mathrm{pH}$ [20-25]. M-S-H gel was first discovered in sulfate-eroded marine concrete [26]. Natural magnesium-rich silicate minerals are reported to adsorb heavy metal ions and hazardous organic compounds $[27,28]$. Synthetic magnesium silicate has excellent adsorption of radioactive $U$ and methylene blue [29,30]. Magnesium silicate systems have also been used to encapsulate nuclear wastes containing active metals such as $\mathrm{Mg}$ and $\mathrm{Al}$. The low $\mathrm{pH}$ and pore solution composition resulted in effective $\mathrm{Al}$ encapsulation with minimal $\mathrm{H}$ generation $[25,31-33]$. Some nuclear wastes contain significant quantities of mixed wastes including the main nuclides $\mathrm{Sr}$ and $\mathrm{Cs}$, and $\mathrm{Mg}$ and $\mathrm{Al}$ alloys. While the high $\mathrm{pH}$ in Portland cement-based binders passivates the corrosion of $\mathrm{Mg}$ alloys, $\mathrm{Al}$ alloys corrode under high $\mathrm{pH}$ conditions with the evolution of $\mathrm{H}_{2}$ gas [26]. The $\mathrm{pH}$ of water in equilibrium with the M-S-H system is in the range from 9.5 to 10.5 and, therefore, the $\mathrm{M}-\mathrm{S}-\mathrm{H}$ system may be suitable for stabilizing this type of nuclear waste [34].

The aim of this research was to assess, for the first time, the effectiveness of $\mathrm{M}-\mathrm{S}-\mathrm{H}$ forming cement systems for the stabilization/solidification of simulated radioactive Sr. The samples formed were leached tested and the compressive strength were determined. In addition, the microstructure was characterized to understand the effect of $\mathrm{Sr}$ addition on hydration reactions and the phases formed.

\section{Experimental}

\subsection{Materials}

Light-burned MgO (Mag Chem 30, M.A.F. Magnesite B.V. Den Haag, The Netherlands) with an $\mathrm{MgO}$ content $>98 \%$ and an activity of $82.16 \%$ was used (Table 1 ). The composition of the silica fume used had a $\mathrm{SiO}_{2}$ content $>97 \%\left(\mathrm{SiO}_{2}\right.$, model 920U, Shanghai Elkem, Shanghai, China), as shown in Table 1. Sodium hexametaphosphate (Na-HMP) with a purity $>95 \%$ was also used (Sinopharm Group, Shanghai, China). The radionuclide ${ }^{90} \mathrm{Sr}$ was replaced with the stable isotope ${ }^{88} \mathrm{Sr}$ and added to samples as strontium nitrate $\left(\mathrm{Sr}\left(\mathrm{NO}_{3}\right)_{2}\right)$ with purity $>95 \%$.

Table 1. Chemical composition of light-burned magnesia and silica fume (wt.\%).

\begin{tabular}{ccccccccc}
\hline Chemical Composition (wt.\%) & $\mathbf{M g O}$ & $\mathbf{C a O}$ & $\mathbf{S i O}_{2}$ & $\mathbf{F e}_{\mathbf{2}} \mathbf{O}_{\mathbf{3}}$ & $\mathbf{A l}_{2} \mathbf{O}_{\mathbf{3}}$ & $\mathbf{K}_{\mathbf{2}} \mathbf{O}$ & $\mathbf{M n O}$ & $\mathbf{S O}_{\mathbf{3}}$ \\
\hline light-burned magnesia & 98.45 & 0.62 & 0.49 & 0.18 & 0.04 & - & 0.04 & - \\
silica fume & 0.45 & 0.43 & 97.34 & 0.05 & 0.12 & 0.97 & 0.04 & 0.35 \\
\hline
\end{tabular}

\subsection{Methods}

The mass ratio of the light-burned $\mathrm{MgO}$ to silica fume was 2:3. The amount of sodium hexametaphosphate added was $2 \mathrm{wt} . \%$ of the total mass of the $\mathrm{MgO}$ and silica fume [34]. The water-to-binder mass ratio varied in different samples between 0.6 and 0.8 and deionized water was used in all mixes. The mass fraction of $\mathrm{Sr}^{2+}$ added as $\mathrm{Sr}\left(\mathrm{NO}_{3}\right)_{2}$ varied from $0.8 \mathrm{wt} . \%$ to $3.2 \mathrm{wt} . \%$ of the total mass of the $\mathrm{MgO}$ and silica fume. 
The raw materials including the required amount of $\operatorname{Sr}\left(\mathrm{NO}_{3}\right)_{2}$ were blended together, and then deionized water containing the Na-HMP was added and mixed to form cement paste samples. This was then poured into $20 \times 20 \times 20 \mathrm{~mm}$ steel moulds to form cubic samples or $\varnothing 50 \times 50 \mathrm{~mm}$ moulds to form cylindrical samples. The samples were removed from the moulds when the samples were sufficiently hard, and then they were stored under standard curing conditions of $20 \pm 2{ }^{\circ} \mathrm{C}$ at a humidity of $>95 \%$.

Samples were tested in compression after curing for 3, 7, and 28 days in accordance with the relevant standard (GB/T 17671-1999) [35]. The leaching tests were completed in accordance with GB/T 7023-2011 [36], the standard test method for leachability of low and intermediate level solidified radioactive waste forms, and GB 14569.1-2011 [37] performance requirements for low- and intermediate-level radioactive waste form-cemented waste form.

The leaching tests used the $\varnothing 50 \times 50 \mathrm{~mm}$ cylindrical samples cured for 28 days. The end faces were polished with sandpaper and the samples were suspended in a polyethylene container using nylon filament. Deionized water and simulated seawater were used as the leachants. The composition of simulated seawater is shown in Table 2. The leachates were replaced after 1, 3, 7, 10, 14, 21, 28, 35 , and 42 days, and the concentration of $\mathrm{Sr}^{2+}$ in the leachate was measured by inductively coupled plasma optical emission spectrometry (ICP-OES). The leaching rate and cumulative amount of $\mathrm{Sr}$ leached were calculated using the following formulas [36]:

$$
\begin{aligned}
& \mathrm{R}_{\mathrm{n}}=\frac{\mathrm{m}_{\mathrm{n}} / \mathrm{m}_{0}}{(\mathrm{~F} / \mathrm{V}) \mathrm{t}_{\mathrm{n}}} \\
& \mathrm{P}_{\mathrm{t}}=\frac{\sum \mathrm{m}_{\mathrm{n}} / \mathrm{m}_{0}}{\mathrm{~F} / \mathrm{V}}
\end{aligned}
$$

where $R_{n}$ is the leaching rate of $\mathrm{Sr}^{2+}$ in the $\mathrm{n}$-th leaching cycle $(\mathrm{cm} / \mathrm{d}) ; \mathrm{m}_{\mathrm{n}}$ is the mass of $\mathrm{Sr}^{2+}$ leached in the $\mathrm{n}$-th leaching cycle (g); $\mathrm{m}_{0}$ is the initial mass of $\mathrm{Sr}^{2+}$ in the leaching test sample $(\mathrm{g}) ; \mathrm{F}$ is the geometric surface area of the sample in contact with the leachate $\left(\mathrm{cm}^{2}\right) ; \mathrm{V}$ is the volume of sample $\left(\mathrm{cm}^{3}\right) ; \mathrm{t}_{\mathrm{n}}$ is the number of days in the $\mathrm{n}$-th leaching cycle; and $\mathrm{P}_{\mathrm{t}}$ is the cumulative leaching fraction of $\mathrm{Sr}^{2+}$ at time $\mathrm{t}(\mathrm{cm})$.

Phase analysis of solidified M-S-H cement samples used X-ray diffraction (XRD; D8 Advance AXS, Brooklyn, Germany) with a Cu target, a working voltage of $40 \mathrm{kV}$, a working current of $40 \mathrm{~mA}$, a scanning range of $5 \sim 80^{\circ}$, and a scanning speed of $0.02^{\circ} 2 \theta / \mathrm{min}$. Scanning electron microscopy (SEM; Nova Nano SEM 450; FEI, Hillsboro, OR, USA) was used to examine the microstructure of the solidified samples at a resolution of $3.5 \mathrm{~nm}$ at $30 \mathrm{kV}$. The test samples examined were taken from a central thin section taken out after crushing the solidified body to a particle size of 3-5 $\mathrm{mm}$. Energy dispersive spectrometry (EDS) was used to perform an elemental analysis of samples.

Table 2. Synthetic components of simulated seawater.

\begin{tabular}{cccccccc}
\hline & $\mathbf{N a C l}$ & $\mathbf{M g C l}_{\mathbf{2}}$ & $\mathbf{N a}_{2} \mathbf{S O}_{4}$ & $\mathbf{C a C l}_{\mathbf{2}}$ & $\mathbf{K C l}$ & $\mathbf{N a H C O}_{3}$ & $\mathbf{K B r}$ \\
\hline Quality/g & 23.50 & 4.98 & 3.92 & 1.10 & 0.66 & 0.19 & 0.09 \\
\hline \multicolumn{7}{c}{ Note: Dilute to 1000 g with water; the ionic strength should be $0.71 \mathrm{~mol} / \mathrm{kg}}$.
\end{tabular}

\section{Results}

\subsection{Compressive Strength}

Figure 1 shows the effect of $\mathrm{Sr}^{2+}$ and the water-cement ratio on the 28-day compressive strengths of $\mathrm{M}-\mathrm{S}-\mathrm{H}$ cement-solidified $\mathrm{Sr}^{2+}$ samples. The compressive strength decreases with increasing water-cement ratio and increasing $\mathrm{Sr}^{2+}$ content. For samples with a water-cement ratio of 0.6 , the compressive strength with a $\mathrm{Sr}^{2+}$ content of $3.2 \mathrm{wt} . \%$ decreased by $48.1 \%$ compared with the control samples. For samples with a water-cement ratio of $0.65-0.8$, the corresponding reductions were $40.7 \%$, $41.8 \%, 38.3 \%$, and $49.8 \%$, respectively. The presence of strontium significantly inhibits the development 
of compressive strength. However, even at the highest water-cement ratio of 0.8 and $\mathrm{Sr}^{2+}$ content of $3.2 \mathrm{wt} . \%$, the 28 -day compressive strength was $\sim 10 \mathrm{MPa}$, which exceeds the $7 \mathrm{MPa}$ required in the specification [36].

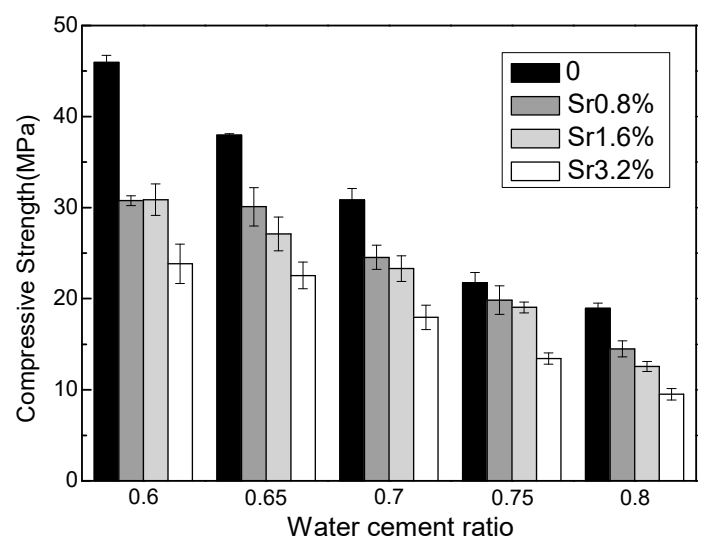

Figure 1. Influence of $\mathrm{Sr}$ content and water-cement ratio on 28-day compressive strength of the $\mathrm{MgO}-\mathrm{SiO}_{2}-\mathrm{H}_{2} \mathrm{O}$ solidified bodies.

\subsection{Crystalline Phase Analysis}

Figure 2 shows XRD data for M-S-H cements with $0 \mathrm{wt} . \%$ and $3.2 \mathrm{wt} . \% \mathrm{Sr}^{2+}$ added. Figure $2 \mathrm{a}$ shows sharp $\mathrm{Mg}(\mathrm{OH})_{2}$ peaks at $18.6^{\circ}, 38.0^{\circ}, 50.8^{\circ}$, and $58.6^{\circ}$. The two peaks at $42.9^{\circ}$ and $62.3^{\circ}$ correspond to $\mathrm{MgO}$. The diffuse background appearing at $2 \theta$ between 32 and $38^{\circ}$ and between 58 and $62^{\circ}$ corresponds to M-S-H gel [34]. This shows that $\mathrm{Mg}(\mathrm{OH})_{2}$ is a reaction product in the initial stages of hydration, accompanied by the formation of some M-S- $\mathrm{H}$ gel. The content of $\mathrm{Mg}(\mathrm{OH})_{2}$ decreases as hydration proceeds.

Figure $2 b$ shows that the addition of $\mathrm{Sr}$ retards hydration. Some $\mathrm{SrCO}_{3}$ identified by the peak at $25^{\circ}$ was present in the hydration products at all ages. Hydration was slower than the control samples without added $\mathrm{Sr}^{2+}$. Some $\mathrm{MgO}$ had not hydrated after 28 days and peaks associated with $\mathrm{Mg}(\mathrm{OH})_{2}$ remained strong and the amount of $\mathrm{M}-\mathrm{S}-\mathrm{H}$ gel was reduced. It is speculated that strontium ions promote the hydrolysis of $\mathrm{MgO}$ to form $\mathrm{Mg}(\mathrm{OH})_{2}$ during the initial stage of hydration, but later compete for hydroxyl ions to form strontium hydroxide, which slows down the rate of $\mathrm{M}-\mathrm{S}-\mathrm{H}$ gel formation in the later stages and leads to the slow development of strength.
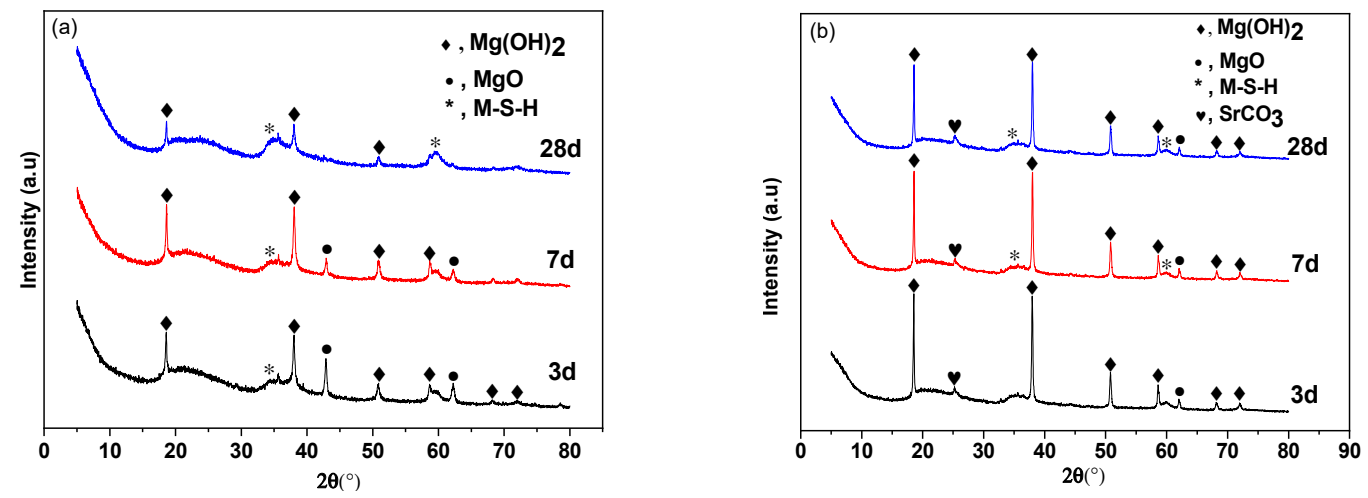

Figure 2. X-ray diffraction spectra of different curing periods of the $\mathrm{MgO}-\mathrm{SiO}_{2}-\mathrm{H}_{2} \mathrm{O}$ solidified bodies with or without added strontium. (a) No added strontium; (b) with $3.2 \mathrm{wt}$ \% added strontium.

\subsection{Microstructural Analysis}

Figure 3 shows SEM images of samples with $0 \mathrm{wt} . \%$ and $3.2 \mathrm{wt} . \% \mathrm{Sr}^{2+}$ hydrated for 3, 7, and 28 days. Figure 3a shows that the hydration products of magnesium silicate cement at the initial stage (three 
days) of hydration were mainly short rod-like magnesium hydroxide crystals. After seven days, the number of $\mathrm{Mg}(\mathrm{OH})_{2}$ crystals decreased, and floc $\mathrm{M}-\mathrm{S}-\mathrm{H}$ gel overlapped the surface of silica fume particles. After hydration for 28 days, compact internal structures were formed, except for some unreacted spherical silica fume particles.
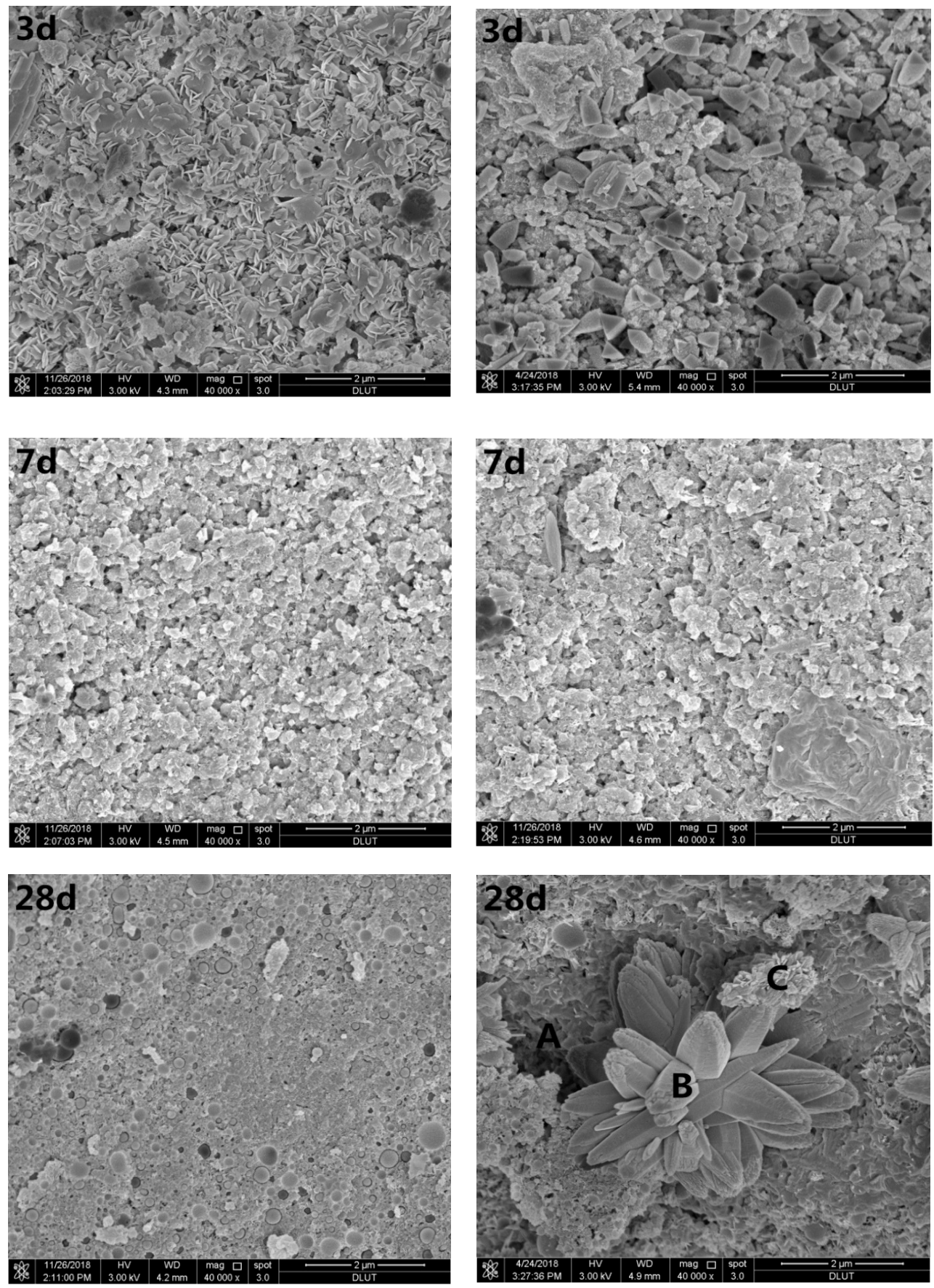

(a) without added strontium

(b) with 3.2 wt.\% strontium

Figure 3. Scanning electron microscopic (SEM) images of different curing periods of the $\mathrm{MgO}-\mathrm{SiO}_{2}-\mathrm{H}_{2} \mathrm{O}$ solidified bodies with or without strontium; (a) without added strontium; (b) with $3.2 \mathrm{wt}$ \% strontium.

Figure $3 b$ shows that solidified $\mathrm{Sr}$ in the magnesium silicate cement affected the $\mathrm{MgO}-\mathrm{SiO}_{2}-\mathrm{H}_{2} \mathrm{O}$ hydration environment. At the beginning of hydration, a large number of pine nut-shaped crystalline $\mathrm{Mg}(\mathrm{OH})_{2}$ structures can be seen, while a small amount of flocculent M-S-H gel was dispersed therein. 
There was also a small number of cubic pyramidal $\mathrm{Mg}(\mathrm{OH})_{2}$ crystals. As the hydration reaction progressed, the number of $\mathrm{Mg}(\mathrm{OH})_{2}$ crystals decreased gradually. After seven days' hydration, the main hydration product was a flocculent $\mathrm{M}-\mathrm{S}-\mathrm{H}$ gel, although some $\mathrm{Mg}(\mathrm{OH})_{2}$ crystals were still present. The crystals basically disappeared from the SEM images after 28 days, while the amount of flocculent substances continued to increase. Specially, a petal-like substance appeared in the sample when the hydration process lasted for 28 days.

EDS analysis of the $\mathrm{MgO}-\mathrm{SiO}_{2}-\mathrm{H}_{2} \mathrm{O}$ solidified body with $3.2 \mathrm{wt} . \% \mathrm{Sr}^{2+}$ after curing for 28 days produced the elemental distribution is shown in Table 3. Strontium ions were mainly concentrated in the petal-like features. The elements in the petals were mainly $\mathrm{C}, \mathrm{O}$, and $\mathrm{Sr}$, and the atomic percentages were $32.30 \%, 54.82 \%$, and $9.20 \%$, respectively. This is characteristic of one type of strontium carbonate and is consistent with the XRD analysis. It can be seen that $\mathrm{Sr}^{2+}$ is chemically bound to the magnesium silicate cement matrix, which is conducive to improving the long-term leaching resistance of the cured body. In addition, the atomic molar ratios of $\mathrm{Mg}$ and $\mathrm{Si}$ in the regions $\mathrm{A}, \mathrm{B}$ and $\mathrm{C}$ were $0.56,0.86$ and 0.76 , respectively, indicative of M-S-H gel [38]. It also shows that the content of unreacted silica fume in the system was high, which indicates that the presence of strontium ions significantly reduces the rate of hydration in magnesium silicate cement.

Table 3. Energy dispersive spectrometry (EDS) analysis of the $\mathrm{MgO}-\mathrm{SiO}_{2}-\mathrm{H}_{2} \mathrm{O}$ solidified body with 3.2 wt. $\% \mathrm{Sr}^{2+}$, cured for 28 days.

\begin{tabular}{ccccccc}
\hline \multirow{2}{*}{ Element } & \multicolumn{2}{c}{ A } & \multicolumn{2}{c}{ B } & \multicolumn{2}{c}{ C } \\
\cline { 2 - 7 } & Weight/\% & Atom/\% & Weight/\% & Atom/\% & Weight/\% & Atom/\% \\
\hline $\mathrm{C}$ & 5.61 & 10.50 & 17.85 & 32.30 & 14.25 & 26.32 \\
$\mathrm{O}$ & 32.52 & 45.72 & 40.36 & 54.82 & 38.52 & 53.43 \\
$\mathrm{Mg}$ & 15.25 & 14.11 & 1.39 & 1.24 & 4.63 & 4.23 \\
$\mathrm{Si}$ & 31.57 & 25.28 & 1.88 & 1.45 & 7.04 & 5.56 \\
$\mathrm{Sr}$ & 13.39 & 3.44 & 37.11 & 9.20 & 32.19 & 8.15 \\
\hline
\end{tabular}

Note: The points A, B, and C are marked in Figure 3b.

\subsection{Leach Test Results}

Figure 4 shows the leaching rate and cumulative fraction leached from solidified bodies with different water-cement ratios doped with $1.6 \mathrm{wt} . \% \mathrm{Sr}^{2+}$ at $25{ }^{\circ} \mathrm{C}$ under deionized water leaching conditions. This indicates that the leaching rate of different water-cement ratios of the magnesium silicate cement solidified body samples initially increased, but then decreased. At the beginning of the leaching test (before seven days), the $\mathrm{Sr}^{2+}$ leaching rate decreased rapidly, but this slowed after seven days. After 28 days, the leaching rate tended to be consistent and gradually reached a steady state. However, the difference in leaching results between the water-cement ratios was small. The effect of the water-cement ratio on leaching from the solidified body of magnesium silicate cement was not obvious. After 42 days of leaching, the maximum leaching rate of each solidified sample was $4.64 \times 10^{-4} \mathrm{~cm} / \mathrm{d}$, and the minimum was $2.53 \times 10^{-4} \mathrm{~cm} / \mathrm{d}$. This was one order of magnitude lower than the limit $\left(1 \times 10^{-3} \mathrm{~cm} / \mathrm{d}\right)$ required by the National Standards. Cumulative leaching from the cumulative fraction leached score curves results during the first 10 days increased rapidly, and the growth rate gradually stabilized after 28 days, which was consistent with the trend in the leaching rate. The 42-day cumulative fraction that leached from all samples was $0.06 \sim 0.07 \mathrm{~cm}$, which only accounted for about 35\% of the specification limit in GB 14569.1-2011 [37], which stipulates that the 42-day cumulative fraction leached from the cement solidified body to $\mathrm{Sr}^{2+}$ is $0.17 \mathrm{~cm}$. 


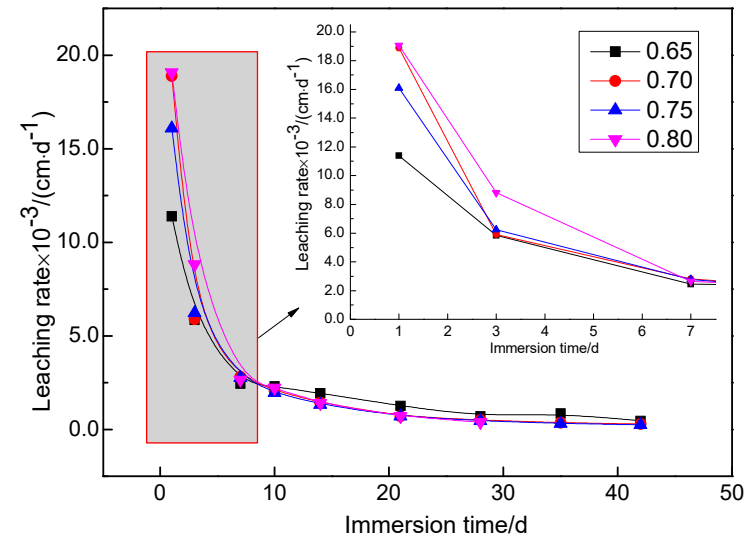

(a)

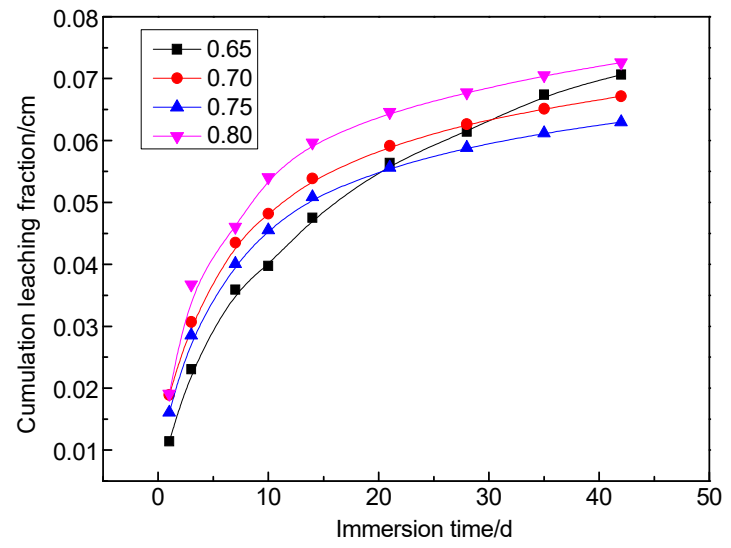

(b)

Figure 4. Leaching rate and cumulative fraction leached curves of different water-cement ratios for the $\mathrm{MgO}-\mathrm{SiO}_{2}-\mathrm{H}_{2} \mathrm{O}$ solidified bodies with $1.6 \mathrm{wt} . \% \mathrm{Sr}^{2+}$ under leaching conditions at an ambient temperature of $25^{\circ} \mathrm{C}$ and using deionized water as leachant. (a) Leaching rate curves (b) Cumulative fraction leached curves

Figure 5 shows the leaching rate and cumulative fraction leached of magnesium silicate cement solidified samples with $1.6 \mathrm{wt} . \%$ strontium using a water-cement ratio of 0.65 under different leaching conditions. In the case of changes in temperature and leachant, the leaching rate and cumulative fraction leached of the solidified body during each leaching period were consistent with those tested at $25{ }^{\circ} \mathrm{C}$ using deionized water as leachant. In contrast, the effect of the leachant on the solidification of $\mathrm{Sr}^{2+}$ by the magnesium silicate cement was more significant than the ambient leaching temperature.

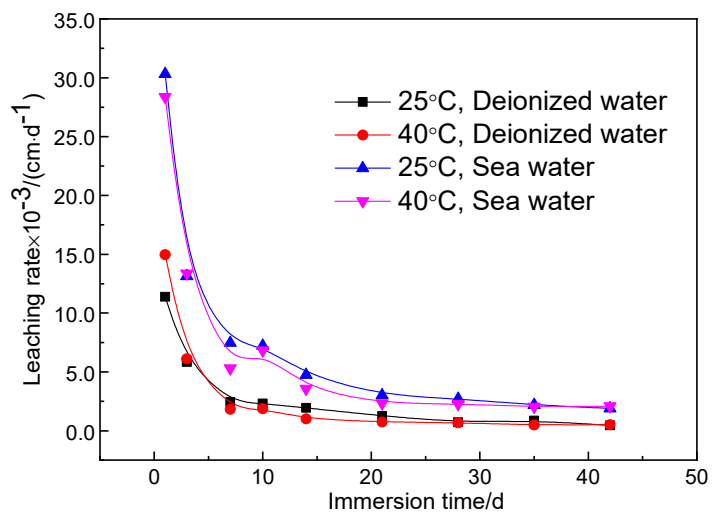

(a)

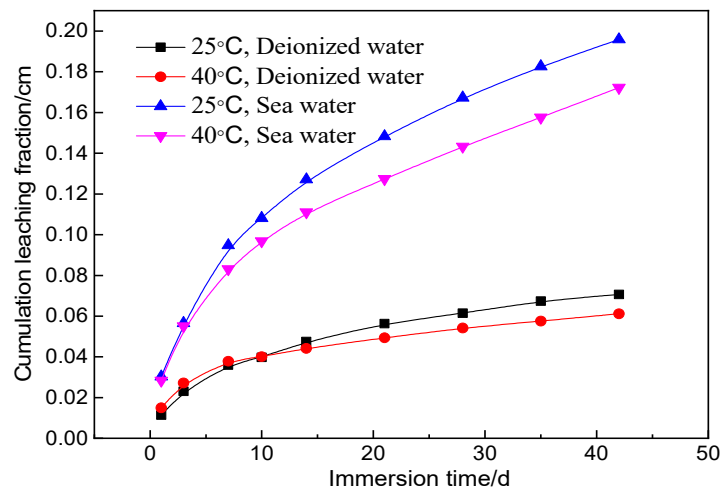

(b)

Figure 5. Leaching rate and cumulative fraction leached curves of the $\mathrm{MgO}-\mathrm{SiO}_{2}-\mathrm{H}_{2} \mathrm{O}$ solidified bodies (water-cement ratio, $0.65 ; \mathrm{Sr}^{2+}$ content, $1.6 \mathrm{wt}$.\%) under different leaching conditions. (a) Leaching rate curves (b) Cumulative fraction leached curves

The leaching rate of the solidified body under simulated seawater conditions improved significantly compared with the results in deionized water. When the ambient leaching temperature was $25^{\circ} \mathrm{C}$, the 42 -day leaching rates of the leachant for deionized water and simulated seawater were $4.64 \times 10^{-4} \mathrm{~cm} / \mathrm{d}$ and $1.89 \times 10^{-3} \mathrm{~cm} / \mathrm{d}$, respectively; the corresponding values were $5.11 \times 10^{-4} \mathrm{~cm} / \mathrm{d}$ and $2.08 \times 10^{-3} \mathrm{~cm} / \mathrm{d}$, respectively, when the temperature was increased to $40^{\circ} \mathrm{C}$. From the cumulative fraction leached curve, when the leaching temperature was $25^{\circ} \mathrm{C}$, the cumulative fraction leached after 42 days under simulated seawater conditions was $0.20 \mathrm{~cm}$, which was 2.9 times that at the same temperature using deionized water $(0.07 \mathrm{~cm})$. When the leaching temperature was $40^{\circ} \mathrm{C}$, the 42 -day cumulative fraction leached under simulated seawater was $0.17 \mathrm{~cm}$, which was about twice that 
with deionized water $(0.06 \mathrm{~cm})$. These results show that the magnesium silicate cement reduces leaching of the radionuclide, particularly in the standard leaching environment $\left(25^{\circ} \mathrm{C}\right.$, deionized water). The 42 -day leaching rate was $<50 \%$ of the standard limit.

Mercury intrusion porosimetry (MIP) test results (Figure 6 and Table 4) show that most pores in the M-S-H solidified body are less than $10 \mathrm{~nm}$ and the total porosity is $\sim 30.5 \%$. This shows that the resistance of nuclide ion diffusion through the pore solution in the material is large, which reduces the leaching rate of the solidified body.

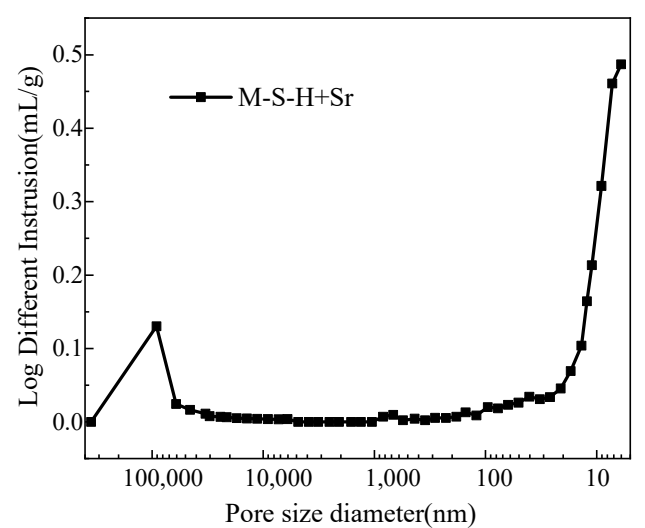

(a)

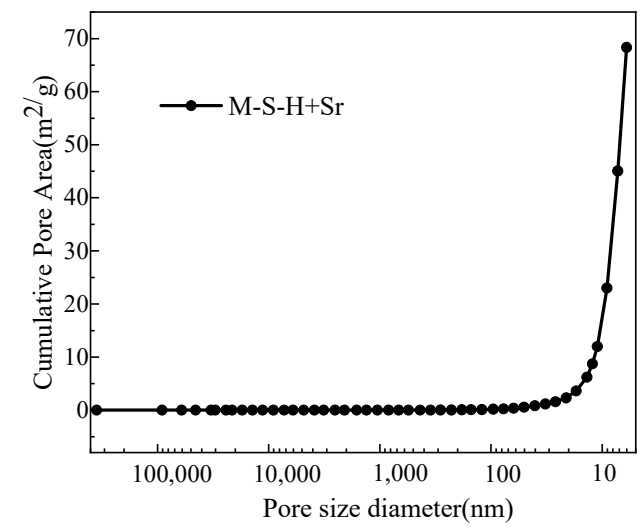

(b)

Figure 6. Mercury intrusion porosimetry (MIP) results of the $\mathrm{MgO}-\mathrm{SiO}_{2}-\mathrm{H}_{2} \mathrm{O}$ solidified body (water-cement ratio, $0.65 ; \mathrm{Sr}^{2+}$ content, $1.6 \mathrm{wt} . \%$ ); (a) log different intrusion; (b) cumulative pore area.

Table 4. Mercury intrusion porosimetry (MIP) results of the $\mathrm{MgO}-\mathrm{SiO}_{2}-\mathrm{H}_{2} \mathrm{O}$ solidified body with 1.6 wt. $\% \mathrm{Sr}^{2+}$.

\begin{tabular}{cccc}
\hline Average Pore Diameter/nm & Median Pore Diameter/nm & Total Pore Area $/ \mathbf{m}^{2} / \mathbf{g}$ & Porosity/\% \\
\hline 15.30 & 8.0 & 68.34 & 30.53 \\
\hline
\end{tabular}

\section{Discussion}

Solidified bodies formed using cement as a substrate material for solidifying waste are a heterogeneous multiphase system composed of various solid products, including hydration products, residual clinkers, radioactive waste, and a small amount of liquid and air existing in the pores. The system solidifies radionuclide ions mainly by physical encapsulation, adsorption, and by forming a solid solution. Encapsulation relies on the density of the cement to retain the nuclide ions and spatially inhibits outward diffusion. Adsorption refers to the adsorption of a nuclide on the surface of the solidified body or hydration products. Forming a solid solution causes improved retention of the nuclide ion compared with the former methods. This is a chemical action that participates nuclides in the internal hydration products of the cement solidified body. According to the experimental results, the solidifying effect of $\mathrm{MgO}-\mathrm{SiO}_{2}-\mathrm{H}_{2} \mathrm{O}$ on the radionuclide included the above ways, indicating that the system has good potential for encapsulating nuclear waste.

The encapsulation effect is mainly related to the pore size distribution of the solidified body, and the pore size distribution of the cement is mainly affected by the water-cement ratio, the admixture, and the curing age. These factors further affect physical properties of the solidified body, such as compressive strength and leaching rate. The presence of strontium changed the hydration environment of the magnesium silicate cement and the fluidity of the system decreased with increases in strontium content. The molding process becomes more difficult resulted in a decrease in the density of the solidified body, so the system does not have obvious advantages for physical inclusion of the nuclide. 
This is the reason that the compressive strength of the solidified body shown in Figure 1 decreased as the water-cement ratio increased. According to the XRD and SEM results, $\mathrm{MgO}$ and $\mathrm{SiO}_{2}$ reacted slowly during the initial stage of hydration and the reaction product was prismatic crystalline $\mathrm{Mg}(\mathrm{OH})_{2}$. As the reaction progresses, $\mathrm{Mg}(\mathrm{OH})_{2}$ hydrates to form $\mathrm{M}-\mathrm{S}-\mathrm{H}$ gel. Previous work has shown that the $\mathrm{M}-\mathrm{S}-\mathrm{H}$ gel is the main strength source in $\mathrm{MgO}-\mathrm{SiO}_{2}-\mathrm{H}_{2} \mathrm{O}$ cements [38] and the compressive strengths of magnesium silicate cement increase at later stages.

Adsorption involves chemical adsorption, which is caused by chemical bonds, mainly through the exchange of specific ions, and physical adsorption, which is generated by intermolecular forces, mainly through surface energy [39]. In addition, the molecular structure of M-S-H gel is close to the molecular structure of sepiolite with a specific surface area of $\sim 200 \mathrm{~m}^{2} / \mathrm{g}$, which has advantages for adsorbing heavy metal ions [40]. The leaching results in Figures 4 and 5 are a good indication of the effect of $\mathrm{MgO}-\mathrm{SiO}_{2}-\mathrm{H}_{2} \mathrm{O}$ cements on limiting the leaching of radionuclide ions.

At the beginning of the leaching tests, part of the $\mathrm{Sr}^{2+}$ adhering to the surface of the solidified

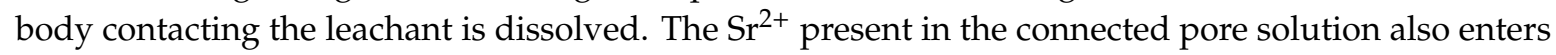
the leachate by liquid-liquid diffusion. The solution in closed pores is in equilibrium with the solid phase. As the leaching period extends, part of the $\mathrm{Sr}^{2+}$ encapsulated inside the solidified body was released gradually to the outer surface of the solidified body by solid phase diffusion, and this can also enter the leaching solution. In addition, the solidified body continues to hydrate during the leaching process, and more hydration products are formed to fill the pores, which reduces the diffusion rate of $\mathrm{Sr}^{2+}$. Therefore, the leaching rate of the magnesium silicate cement solidified body tends to be high during the early stage and low during the later stages. In addition, the SEM image in Figure 3 shows that Sr participates in the hydration process of the magnesium silicate cement, changing the final hydration product type, and existing in the solidified body in the form of strontium carbonate. Although this reduced the strength of the solidified body, the leaching resistance of the magnesium silicate cement solidified body was improved.

\section{Conclusions}

The effect of $\mathrm{Sr}^{2+}$ on the hydration process of $\mathrm{MgO}-\mathrm{SiO}_{2}-\mathrm{H}_{2} \mathrm{O}$ cement was evaluated by assessing the mechanical properties, the phases, and by microstructural analysis. From results of strength, leaching tests and pore diameter distribution analysis, the stabilization performance of the M-S-H cement on $\mathrm{Sr}^{2+}$ was revealed and the following conclusions were drawn:

(1) Incorporating the Sr nuclide reduced the working performance of the magnesium silicate cement and inhibited the development of compressive strength owing to the inhibition of hydration process.

(2) The leaching rate and cumulative leaching fraction of the solidified body after immersion for 42 days in the standard environment $\left(4.64 \times 10^{-4} \mathrm{~cm} / \mathrm{d}\right)$ and high temperature seawater $\left(1.89 \times 10^{-3} \mathrm{~cm} / \mathrm{d}\right)$ were one order of magnitude lower than the limit value in the National Standard.

(3) The presence of Sr affected the hydration reactions of the magnesium silicate cement and was encapsulated the interior of the matrix in the form of a strontium carbonate precipitate. This was beneficial to ensure low long-term leaching performance of the solidified body.

Author Contributions: T.Z. and Y.J. conceived and designed the experiments; J.Z. and Y.L. performed the experiments; Y.J. and J.Z. analyzed the data; T.Z. contributed reagents/materials/analysis tools; J.Z. wrote the paper; Y.J. and C.R.C. reviewed the paper. All authors have read and agreed to the published version of the manuscript.

Funding: This research was funded by [National Natural Science Foundation of China] grant number [No. 51778101; No. 61704017; No. 51808217], [National Key R\&D program of China] grant number [2017YFE0107000], [State Key Laboratory of Coastal and Offshore engineering of Dalian University of Technology] grant number [LP1808], [Dalian High-level Talent Innovation Program] grant number [2017RQ051], [The fundamental Research Funds for the Central Universities] grant number [DUT19JC27], [Natural Science Foundation of Hebei Province] grant number [E2019209403], [Key R\&D Program of Hebei Province] grant number [19273803D] and [Post-doctoral Research Project of Hebei Province] grant number [B2019003028]. 
Acknowledgments: The authors wish to express their gratitude and sincere appreciation for the financial support provided by the National Natural Science Foundation of China, Institute of Building Materials (Dalian University of Technology) and Hebei Provincial Key Laboratory of Inorganic Nonmetallic Materials (North China University of Science and Technology).

Conflicts of Interest: The authors declare no conflict of interest.

\section{References}

1. IAEA. Classification of Radioactive Waste; Safety Series GSG-1; IAEA: Vienna, Austria, 2009.

2. Hashimoto, S.; Matsuura, T.; Nanko, K.; Linkov, I.; Shaw, G.; Kaneko, S. Predicted spatio-temporal dynamics of radio cesium deposited onto forests following the Fukushima nuclear accident. Sci. Rep. 2013, 3, 2564. [CrossRef] [PubMed]

3. Koarashi, J.; Atarashi-Andoh, M.; Amano, H.; Matsunaga, T. Vertical distributions of global fallout ${ }^{137} \mathrm{Cs}$ and ${ }^{14} \mathrm{C}$ in a Japanese forest soil profile and their implications for the fate and migration processes of Fukushima-derived ${ }^{137}$ Cs. J. Radioanal. Nucl. Chem. 2017, 311, 473-481. [CrossRef]

4. Ota, M.; Nagai, H.; Koarashi, J. Modeling dynamics of ${ }^{137} \mathrm{Cs}$ in forest surface environments: Application to a contaminated forest site near Fukushima and assessment of potential impacts of soil organic matter interactions. Sci. Total Environ. 2016, 551, 590-604. [CrossRef] [PubMed]

5. Buesseler, K.O.; Jayne, S.R.; Fisher, N.S.; Rypina, I.I.; Baumann, H.; Baumann, Z.; Breier, C.F.; Casacuberta, E.M.; Masqué, N.P.; Garcia-Orellana, J.; et al. ${ }^{90} \mathrm{Sr}$ and ${ }^{89} \mathrm{Sr}$ in seawater off Japan as a consequence of the Fukushima Dai-ichi nuclear accident. Bioresources 2013, 10, 3649-3659. [CrossRef]

6. Kubota, T.; Shibahara, Y.; Fukutani, S.; Fujii, T.; Ohta, T.; Kowatari, M.; Mizuno, S.; Takamiya, K.; Yamana, H. Cherenkov counting of ${ }^{90} \mathrm{Sr}$ and ${ }^{90} \mathrm{Y}$ in bark and leaf samples collected around Fukushima Daiichi Nuclear Power Plant. J. Radioanal. Nucl. Chem. 2015, 303, 39-46. [CrossRef]

7. Steinhauser, G.; Schauer, V.; Shozugawa, K. Concentration of Strontium-90 at selected hot spots in Japan. PLoS ONE 2013, 8, e57760. [CrossRef] [PubMed]

8. Toth, F.L.; Rogner, H.H. Oil and nuclear power: Past, present, and future. Energy Econ. 2006, $28,1-25$. [CrossRef]

9. Halim, C.E.; Amal, R.; Beydoun, D.; Scott, J.A.; Low, G. Low, Implications of the structure of cementitious wastes containing Pb (II), Cd (II), As (V), and Cr (VI) on the leaching of metals. Cem. Concr. Res. 2004, 34, 1093-1102. [CrossRef]

10. Shi, C.J.; Fernández-Jiménez, A. Stabilization/solidification of hazardous and radioactive wastes with alkali-activated cements. J. Hazard. Mater. 2006, 137, 1656-1663. [CrossRef]

11. Qian, G.G.; Sun, D.D.; Tay, J.H. New aluminium-rich alkali slag matrix with clay minerals for immobilizing simulated radioactive Sr and Cs waste. J. Nucl. Mater. 2001, 299, 199-204. [CrossRef]

12. Guangren, Q.; Yuxiang, L.; Facheng, Y.; Rongming, S. Improvement of metakaolin on radioactive Sr and Cs immobilization of alkali-activated slag matrix. J. Hazard. Mater. 2002, 92, 289-300. [CrossRef]

13. Plecas, I.; Pavlovic, R.; Paclovic, S. Leaching behavior of ${ }^{60} \mathrm{Co}$ and ${ }^{137} \mathrm{Cs}$ from spent ion exchange resins in cement-bentonite clay matrix. J. Nucl. Mater. 2004, 327, 171-174. [CrossRef]

14. Wei, M.L. Research on Mechanism and Long-Term Performance of a New Phosphate-Based Binder for Stabilization of Soils Contaminated with High Levels of Zinc and Lead. Ph.D. Thesis, Southeast University, Nanjing, China, 2017.

15. Zhang, H.; He, P.J.; Shao, L.M. Fate of heavy metals during municipal solid waste incineration in Shanghai. J. Hazard. Mater. 2008, 156, 365-373. [CrossRef] [PubMed]

16. Cao, X.; Wahbi, A.; Ma, L.; Li, B.; Yang, Y. Immobilization of $\mathrm{Zn}, \mathrm{Cu}$, and $\mathrm{Pb}$ in contaminated soils using phosphate rock and phosphoric acid. J. Hazard. Mater. 2009, 164, 555-564. [CrossRef] [PubMed]

17. You, C.; Qian, J.; Qin, J.; Wang, H.; Wang, Q.; Ye, Z. Effect of early hydration temperature on hydration product and strength development of magnesium phosphate cement (MPC). Cem. Concr. Res. 2015, 78, 179-189. [CrossRef]

18. Lai, Z.; Lai, X.; Shi, J.; Lu, Z. Effect of $\mathrm{Zn}^{2+}$ on the early hydration behavior of potassium phosphate based magnesium phosphate cement. Constr. Build. Mater. 2016, 129, 70-78. [CrossRef]

19. Lai, Z.Y.; Qian, J.S.; Liang, P. Study on the curing properties of ${ }^{90} \mathrm{Sr}$ by magnesium phosphate cement. Acta Sci. Circumstantiae 2011, 31, 2792-2797. [CrossRef] 
20. Qiao, F.; Chau, C.K.; Li, Z. Property evaluation of magnesium phosphate cement mortar as patch repair material. Constr. Build. Mater. 2010, 24, 695-700. [CrossRef]

21. Fei, J.; Al-Tabbaa, A. Strength and hydration products of reactive MgO-silica pastes. Cem. Concr. Compos. 2014, 52, 27-33. [CrossRef]

22. Fei, J.; Gu, K.; Al-Tabbaa, A. Strength and drying shrinkage of reactive MgO modified alkali-activated slag paste. Constr. Build. Mater. 2014, 51, 395-404. [CrossRef]

23. Li, Z.; Zhang, T.; Hu, J.; Tang, Y.; Niu, Y.; Wei, J.; Yu, Q. Characterization of reaction products and reaction process of $\mathrm{MgO}-\mathrm{SiO} 2-\mathrm{H} 2 \mathrm{O}$ system at room temperature. Constr. Build. Mater. 2014, 61, 252-259. [CrossRef]

24. Wei, J.X. Study on $\mathrm{MgO}-\mathrm{SiO}_{2}-\mathrm{H}_{2} \mathrm{O}$ Cementitious System and Its Mechanism of Hydration and Hardenin; China Academy of Building Materials Science: Beijing, China, 2004.

25. Wei, J.X.; Chen, Y.M.; Li, Y.X. The reaction mechanism between $\mathrm{MgO}$ and microsilica at room temperature. J. Wuhan Univ. Technol. Mater. Sci. Ed. 2006, 21, 88-91. [CrossRef]

26. Zhang, T.T.; Cheesemana, C.R.; Vandeperre, L.J. Development of low $\mathrm{pH}$ cement systems forming magnesium silicate hydrate (M-S-H). Cem. Concr. Res. 2011, 41, 439-442. [CrossRef]

27. Cole, W.F.; Demediuk, T. X-Ray, thermal, and Dehydration studies on Magnesium oxychlorides. Aust. J. Chem. 1955, 8, 234-251. [CrossRef]

28. Sevim, A.M.; Hojiyev, R.; Gül, A.; Çelik, M.S. An investigation of the kinetics and thermodynamics of the adsorption of a cationic cobalt porphyrazine onto sepiolite. Dyes Pigments 2011, 88, 25-38. [CrossRef]

29. Alexandre-Franco, M.; Albarrán-Liso, A.; Gómez-Serrano, V. An identification study of vermiculites and micas: Adsorption of metal ions in aqueous solution. Fuel Process. Technol. 2011, 92, 200-205. [CrossRef]

30. Franco, F. Adsorption of Methylene Blue on magnesium silicate: Kinetics, equilibria and comparison with other adsorbents. J. Environ. Sci. 2010, 22, 467-473. [CrossRef]

31. Fouad, H.K.; Bishay, A.F. Uranium uptake from acidic solutions using synthetic titanium and magnesium based adsorbents. J. Radioanal. Nucl. Chem. 2010, 283, 765-772. [CrossRef]

32. Zhang, T.T.; Vandeperre, L.J.; Cheeseman, C. Magnesium-silicate-hydrate cements for encapsulating problematic aluminium containing wastes. J. Sustain. Cem.-Based Mater. 2012, 1, 34-45. [CrossRef]

33. Zhang, T.T.; Vandeperre, L.J.; Christopher, R. Formation of magnesium silicate hydrate (M-S-H) cement pastes using sodium hexametaphosphate. Cem. Concr. Res. 2014, 65, 8-14. [CrossRef]

34. Jia, Y. The Effect of $\mathrm{Na}-\mathrm{HMP}$ and $\mathrm{CaO}$ on the Reaction Mechanism of $\mathrm{MgO}-\mathrm{SiO}_{2}-\mathrm{H}_{2} \mathrm{O}$ System; Dalian University of Technology: Dalian, China, 2017.

35. GB/T 17671-1999. Determinations for Isotopes of Lead, Strontium and Neodymium in Rock Samples. Available online: https://books.google.com.br/books?id=ghrVAwAAQBAJ\&pg=PA477\&lpg=PA477\&dq= GB/T+17671-19992011 (accessed on 10 December 2019).

36. GB/T 7023-2011. Standard Test Method for Leachability of Low and Intermediate Level Solidified Radioactive Waste Forms. Available online: https://www.chinesestandard.net/PDF/English.aspx/GBT7023-2011 (accessed on 10 December 2019).

37. GB 14569.1-2011. Performance Requirements for Low and Intermediate Level Radioactive Waste Form-Cemented Waste Form. Available online: http://english.mee.gov.cn/Resources/standards/ Radioactivity/radiation/201111/t20111101_219413.shtml (accessed on 10 December 2019).

38. Li, Z.H. Reaction Mechanisms and Application Study of $\mathrm{MgO}-\mathrm{SiO}_{2}-\mathrm{H}_{2} \mathrm{O}$ Cementitious System; South China University of Technology: Guangzhou, China, 2015.

39. Lai, Z.Y. Study on Solidification of Low and Medium Radioactive Waste with Magnesium Phosphate Cement; Chongqing University: Chongqing, China, 2012.

40. Brew, D.R.M.; Glasser, F.P. Synthesis and characterisation of magnesium silicate hydrate gels. Cem. Concr. Res. 2005, 35, 85-98. [CrossRef]

(C) 2020 by the authors. Licensee MDPI, Basel, Switzerland. This article is an open access article distributed under the terms and conditions of the Creative Commons Attribution (CC BY) license (http://creativecommons.org/licenses/by/4.0/). 